\title{
Introduction
}

\section{Genealogies of European governance}

\author{
Mark Bevir ${ }^{\mathrm{a}, *}$ and Ryan Phillips ${ }^{\mathrm{b}}$ \\ ${ }^{a}$ Department of Political Science, University of California, Berkeley, 210 Barrows Hall \#1950, Berkeley, \\ CA 94720 , USA. \\ E-mail: mbevir@berkeley.edu \\ ${ }^{\mathrm{b}}$ Government and International Relations Department, Connecticut College, 270 Mohegan Avenue, \\ New London, CT 06320, USA. \\ E-mail: ryan.phillips@conncoll.edu \\ *Corresponding author.
}

\begin{abstract}
How should scholars study European governance? In this introductory article, we situate our genealogical approach in relation to existing research by summarizing the key features of major strands of research on European governance, clarifying their primary similarities and differences, criticizing their underlying commitment to the development of comprehensive theories and articulating the beginnings of an alternative research agenda. This alternative research agenda pivots away from attempting to develop a comprehensive theoretical model of European governance to one oriented towards investigating the beliefs and narrative traditions that shape Europe's governing practices. We conclude by previewing the contributions to the Special Issue, drawing attention to the overlapping themes addressed in each article, namely the influence of social scientific rationalities, elite narratives and local traditions in contemporary forms of European governance.

Comparative European Politics (2017) 15, 685-704. doi:10.1057/s41295-016-0080-8; published online 24 October 2016
\end{abstract}

Keywords: European governance; genealogy; historicism; interpretivism

\section{Introduction}

Scholars often define governance in contrast to government; whereas government was about hierarchy and bureaucracy, governance is about decentralized markets and networks (Delanty and Rumford, 2005: 142-146; Eising and Kohler-Koch, 1999: 3-4; Jachtenfuchs, 1995: 124-125; Kohler-Koch, 1999: 14; Kohler-Koch and Rittberger, 2006: 28). Since the early 1990s, the concept of governance has had a significant impact on the study of Europe and the European Union (Caporaso and Wittenbrinck, 2006; Hix, 1998; Jachtenfuchs, 2001; Pollack, 2005).

(C) 2016 Macmillan Publishers Ltd. 1472-4790 Comparative European Politics Vol. 15, 5, 685-704 
Because scholars tend to conceptualize governance in contrast to government, existing research has led to vigorous debates about whether member states have lost influence to other actors, whether the number of networks has risen, how EU governance affects national patterns of politics and policy-making, and how compliance and accountability can be achieved. Although these debates cast light on some issues, they suggest an overly monolithic view of governance - as if governance can be identified with a new pattern of hollowing out of the nation state, Europeanization or multi-level institutions, and as if that pattern is a necessary result of broader socio-economic changes (Delanty and Rumford, 2005: 143).

Like previous attempts to theorize European integration (Anderson, 2009; Gillingham, 2003; Haas, 2004; Milward, 1984, 1999; Moravcsik, 1998), research on European governance attempts to develop comprehensive theories of its nature and development. Frequently described as "middle-range theories" by their advocates, these theories aspire to be comprehensive by proposing to explain some existing pattern of behavior or outcomes on the basis of an underlying social logic. We believe such an approach is philosophically misguided. As a result, this Special Issue seeks to rethink governance not as a particular state formation, but as a set of meaningful practices, informed by various beliefs, concepts and desires. In particular, the five articles focus on the influence of scientific rationalities, elite narratives and local traditions on practices of European governance. Such a reorientation leads to the historical investigation of the complex webs of belief that inform those practices and the contests that accompany them.

In this introductory article, we situate the contributions of the Special Issue in relation to existing research on European governance. We begin by demonstrating how existing research treats European governance as a novel state formation and that existing theories aspire to be comprehensive accounts of the nature and development of European governance based on the alleged existence of underlying social logics. Then we explain and justify our understanding of European governance as set of meaningful practices and how this reconceptualization leads to a different research agenda, one that pivots away from attempts to develop comprehensive theoretical models to one oriented towards investigating the beliefs and narrative traditions that shape Europe's governing practices. In short, we advocate a shift to historicist explanations of ideas and practices, or genealogy. Finally, we summarize the contributions of each article and highlight how they exhibit the themes of central interest in this Special Issue: social science rationalities, elite narratives and local traditions.

\section{Governance Research}

In the 1990s, governance approaches emerged as a rival to International Relations and comparativist approaches to the study of the EU (Hix, 1998; Pollack, 2005: 
379-390). ${ }^{1}$ Like comparativists, governance scholars were responding to what they viewed as the changing nature of the Union. However, unlike comparativists (Hix, 1994, 1998, 2006) governance scholars generally did not draw the conclusion that the EU was becoming increasingly similar to national political systems. As a result, they rejected the tendency to adopt "off-the-shelf" models and theories drawn from the study of domestic politics (Pollack, 2005: 380). Even those scholars whose theories were directly inspired by the study of domestic policy-making - for instance, Giandemenico Majone (Majone, 1996) - the idea of governance signalled the arrival of a new type of political system in Europe. This new political system was distinct from conceptualizing the EU as either an international organization or federal government.

While research on European governance shares a common point of departure rejecting the view that the EU is adequately conceptualized as either an international organization or federal government - similar to the treatment of "governance" in other fields, "European governance" is an "umbrella concept", covering a number of different uses (Rhodes, 1996). On this point, we depart from other commentators who see governance as a relatively coherent approach to the study of the EU (Hix, 1998; Jachtenfuchs, 2001; Kohler-Koch and Rittberger, 2006; Pollack, 2005). Four different uses stand out: multi-level governance, network governance, regulatory governance and experimentalist governance. ${ }^{2}$ Although overlapping in certain respects, these four strands of research (1) conceptualize European governance differently, (2) identify different phenomena or processes by the term, (3) draw different conclusions about the significance of European governance, (4) provide different explanations of why Europe and the EU were transformed into a system of governance, (5) make different claims about how governance affects policy-making and (6) debate different problems. In our summary of the research, we draw attention to these six points of contrast.

Despite these differences, research on European governance is presented as a set of mid-range theories that provide comprehensive accounts (or potentially comprehensive dependent on future empirical confirmation) of Europe or the EU as a type of political regime or polity (see for instance Kohler-Koch, 1999: 14-15). These theories aspire to comprehensiveness by unpacking the essential properties of European governance, explaining the rise of governance as the outcome of certain conditions or structures and asserting that the essential properties of European governance explain a novel pattern of rule or state formation. In Sect. 3, we explain why the attempt to produce a comprehensive account of European governance is impossible and therefore why the reconceptualization of governance pursued by this Special Issue is justified. In this section, however, we simply note that theories of multi-level governance, network governance, regulatory governance and experimentalist governance are presented as comprehensive accounts of European governance based on the alleged existence of various social logics. 


\section{Multi-level governance}

For scholars of multi-level governance (MLG), European integration and policymaking have led to a dispersion of authority and influence amongst national, EU and subnational governmental actors (Bolleyer et al, 2014; Hooghe and Marks, 2008; Kohler-Koch and Rittberger, 2009: 7-8; Marks et al, 1996). The EU polity is "multi-level" in the sense that state actors at various territorial levels share authority in the policy-making process. EU policy-making is characterized by "governance" because it features "mutual dependence, complementary functions and overlapping competencies" (Marks et al, 1996: 372). EU institutions, national and subnational governments share authority and influence.

The transformation of the EU into a multi-level polity is said to result in two important outcomes. First, state executives no longer exert sole control over the representation of domestic interests or values at the EU level. European integration has led state executives to lose their monopoly on domestic interest mediation to supranational institutions and subnational groups. Second, different levels of government have become dependent on resources controlled by actors at other levels (Pollack, 2005). Governmental actors possess different resources, like information, economic assets and public authority. Effective policy-making requires bringing all these resources to bear on an issue. While scholars of MLG do not deny that state executives are important, or even the most important actors in the policy process, because national governments are no longer the exclusive representatives of domestic interests and effective policy-making depends on contributions by various parties, they conclude that a broad range of public actors hold considerable sway in the policy process and outcomes are determined by the interdependence of European and domestic levels of government (Jachtenfuchs, 2006).

Scholars cite a number of factors to explain the transformation of the EU from a system of sovereign states into a system of MLG: the changing scale of collective problems, the post-war expansion of the national policy portfolio and geopolitics, the benefits that are achieved through shifting decision-making power to the supranational level, the limited influence of individual states due to decisionmaking rules and the loss of control experienced by state executives once supranational institutions are created (Marks et al, 1996). First, governmental leaders face functional pressures from the changing scale of collective problems. Where the problems are transnational in scope, the most effective level of decisionmaking is similarly transnational. Second, post-WWII states have taken on a much broader range of policies related to economic growth and welfare. And achieving national policy goals frequently requires transnational cooperation. Third, and relatedly, governmental leaders benefit from shifting decision-making to the supranational level. Not only does it allow them to deliver policy outcomes voters 
desire, but it also allows them to shift blame onto Brussels for unpopular decisions and insulate decision-making from domestic pressures after they leave office. Fourth, state executives have limited control over the activities and make-up of supranational institutions like the Commission and European Court of Justice. Combined with the extension of qualified majority voting in the Council, individual governments are frequently unable to determine outcomes. Finally, European integration occurred at a time when the pressures of superpower rivalry encouraged, rather than discouraged, reducing barriers to trade across Western Europe. Given these factors, member states came to share domestic interest representation and policy influence with supranational and subnational public actors.

Research on MLG has addressed the influence of supranational and subnational groups in policy-making and the breadth as well as the depth of integration, including variation across policy areas. Debates in the study of MLG include the changing role of the state, the extent to which non-public actors are involved in decision-making, the importance of networks rather than hierarchy in relations between actors, the extent to which authority across governance levels is fragmented versus interlocking and the implications of MLG for democratic accountability (Bache and Flinders, 2004; Hooghe and Marks, 2008). One prominent offshoot of MLG is the study of "Europeanization" or the interactions between the EU and member states as well as third countries. Top-down perspectives on Europeanization address the impact of European integration on national institutions, policies and politics. Alternatively, bottom-up perspectives address to what extent and through what processes domestic actors upload their preferences over EU policies, processes and institutions (Kohler-Koch, 1999; Jachtenfuchs, 2001: 250-251; Kohler-Koch and Rittberger, 2006: 38; Graziano and Vink, 2007; Ladrech, 2010; Börzel and Panke, 2013).

\section{Network governance ${ }^{3}$}

MLG and network theory share obvious affinities in their focus on the dispersion of influence amongst different actors throughout the policy process. ${ }^{4}$ However, whereas MLG tends to focus on governmental actors at different territorial levels, network theory scrutinizes public and private actors at the same ("horizontal networks") or different territorial levels ("vertical networks") (Peterson, 2004: 132).

According to one prominent definition, a network is "a set of relatively stable relationships which are of [a] non-hierarchical and interdependent nature linking a variety of actors, who share a common interest with regard to a policy and who exchange resources to pursue these shared interests acknowledging the cooperation is the best way to achieve common goals" (Börzel, 1998: 254). A network includes all public and private actors involved in the design and 
implementation of policy in a particular policy sector. Network governance refers to a process of governing in the absence of a central authority in which the political arena is populated by public and private actors linked together through a variety of resource interdependencies (Eising and Kohler-Koch, 1999: 4).

The transformation of the EU into a networked polity is said to have two important impacts. First, the EU is a highly differentiated polity. Across different policy sectors, decision rules and dominant actors vary considerably. The processes and actors that shape, say, environmental policy (Braun, 2009; Jordan and Schout, 2006) and trade policy (Dür, 2008) are quite distinct. Furthermore, European governance is built on top of highly developed subsystems that contain their own logics and dynamics. The segmentation of society and the state into different governance networks means that political arenas and societal subsystems develop their own political logics that are only loosely associated with other political arenas (Eising and Kohler-Koch, 1999: 4). Second, many policy areas are highly technical and tend to be dominated by experts. This is said to be especially evident in social and environmental regulation. Policy-making in these areas gathers together EUindependent bodies as well as public and private experts. At every stage of the policy-making process - agenda formation, decision-making, implementation and adjudication - the Union relies upon committees of officials and other stakeholders. (Kohler-Koch, 1999: 24-26; Peterson, 2004: 117-118).

Explanations of the emergence of network governance in Europe point to five factors. First, public and private actors shared the belief that the legitimacy of the European project was to be based on functional representation, technocratic regulation and institutionalized deliberation. This shared understanding of the bases of legitimate European policy-making justified the participation of a variety of state and societal actors. Second, the Commission acted as a political entrepreneur in order to strengthen its own influence relative to other EU institutions and achieve policy outcomes in line with its preferences. As a result, it actively recruited economic and social actors to participate in EU policy-making that aligned with its institutional and policy goals. Third, to enhance their autonomy from national governments and increase their influence in European affairs, subnational groups sought avenues of interest representation at the EU level. One result of this domestic agitation was the creation of the Committee of the Regions, which over time gained access to an increasing number of policy fields. Fourth, in order to exert greater influence on decisions that impacted their interests, corporate actors and interest associations forged transnational links to lobby in Brussels. And finally, the transformation of EU legal acts into a system of supranational law empowered EU citizens to take legal action against their governments. The result of these factors was the formal and informal institutionalization of a policy-making process that relies on the actions of various public and private actors at different territorial levels (Kohler-Koch, 1999: 18-20). 
Network theorists offer competing accounts of the logic of network governance. Some claim that the structure of networks has a significant influence on how members interact, the policy-making process and policy outcomes. Although different typologies of networks exist in the literature (Börzel, 1998), network theorists tend to argue that the relative stability of membership, their openness to individuals and groups and the level of resource interdependence amongst actors determine the relative influence of various actors and the substantive content of EU policies (Peterson, 2004: 120). Variation in these variables, and thus variation in the internal structure of networks, is alleged to produce different outcomes (Börzel, 1998: 254). Others argue that the structural properties of the EC/EU like the allocation of competences, formal and informal decision-making rules, administrative routines and comitology, alongside intersubjectively shared belief systems regarding legitimate political action generate a particular system of governance, characterized by state mediation (rather than authoritative allocation), mixed motive behavior, novel patterns of interaction and multi-level coordination (Kohler-Koch, 1999). In either version, variations in the essential characteristics of network governance are said to give rise to a novel system of rule.

Network analysis has been used to explain the relative influence of national or supranational interests in negotiations over policy, the role of political advocacy coalitions and epistemic communities in bringing about policy shifts, domestic interest mediation in EU foreign policy-making (Fischer and Sciarini, 2013), the building of regional cross-border cooperation (Perkmann, 1999), the evolution of the EU's emission trading scheme (Braun, 2009), Cohesion Policy and the Common Agricultural Policy. Debates over network governance have focused on the performance of network governance (Schout et al, 2010), the extent to which the EU is governed through networks, how European network governance affects national patterns of governance and the legitimacy of network governance (KohlerKoch and Eising, 1999).

\section{Regulatory governance}

For other scholars, most notably Giandomenico Majone, governance refers to a distinctive mode of policy-making: the replacement of public ownership, planning and centralized administration by regulation as a model of state intervention in the economy and society (Majone, 1994, 1996, 1999). EU governance, in this view, is regulatory governance, defined as the "sustained and focused control exercised by a public agency over activities that are socially valued" (Majone, 1994).

According to Majone, statutory regulation by independent agencies is the most important form of policy-making conducted at the EU level (Majone, 1999: 2), encompassing an increasing number of policy areas, including consumer product safety, medical drug testing, research and technological development, education, tourism, banking and financial services, competition law and the environment. Two 
features of the EU's regulatory role stand out (Majone, 1994). First, the creation of the single European market depended on the internationalization of regulation. Through addressing monopolistic practices, providing information and controlling negative externalities, EU institutions and agencies - and the Commission above all others - has been able to overcome problems of regulatory failure endemic to international contexts and thereby Europeanize national markets. Second, because regulation is a very specialized type of policy-making, it tends to be dominated by experts and requires high levels of administrative discretion. As a result, significant policy-making powers have been delegated to independent institutions. These two features of EU regulation are connected. Expert decision-making insulated from political interference underpins the EU's market-making capacity.

Majone traces the development of the EU into a regulatory state to both general trends in public governance and specific factors that influenced the EU. ${ }^{5}$ First, the failure of public ownership and the privatization of state enterprises and key industries across Europe led to the use of regulation to correct market failures, improve the efficiency of the economy and protect the public interest. The role of the state changed from being a producer of goods to an umpire of the rules of the game (Eberlein and Grande, 2005: 90). Second, public officials perceived a mismatch between institutional capacities and the growing complexity and interdependence of social problems. The "policing of financial markets in an interdependent world; controlling the risks of new products and technologies to the public; protecting the health and economic interests of consumers without impeding the free flow of goods, services and people across national boundaries; and reducing environmental pollution" outstripped the capacities of individual states and were not soluble by old-style command and control techniques (Majone, 1994). The delegation of policy-making to supranational experts who possessed both the technical capability and discretion to respond to an ever changing, interconnected world allowed national governments to achieve a level of policy effectiveness they could not achieve on their own (Majone, 1996: 4). Third, the EU is limited in its ability to tax and spend. Because the EU's budget is small and constrained to supporting a few (re)distributive programmes (e.g. Common Agricultural Policy), the capacity to support direct-expenditure programmes was quite limited. Tax and spending activities typical of national governments were blocked. Fourth, given the EU's limited budgetary resources, the only way for the Commission to increase its influence was to expand its role in regulatory activities. Regulation was the optimal option because the cost of producing regulations was small and the costs of compliance were born by the firms and individuals as well as member states who were responsible for enforcement. The Commission's role was supported by export-oriented industries in Europe that had a strong incentive to push for European-level regulation to avoid inconsistent and progressively more stringent regulations in EC and non-EC countries. Fifth, member states were willing to surrender important regulatory powers to supranational institutions 
because intergovernmental solutions were not credible. Individual governments lacked the ability or incentive to verify and enforce intergovernmental agreements. Finally, not only did the Commission have the incentive to play a major role in regulatory policy, but it also had the ability to be an effective policy entrepreneur given the highly talented and motivated staff that it recruited and its central role in issue networks. In sum, the rise of European regulatory governance was the result of a confluence of factors: general trends of privatization, deregulation and regulatory failure in the face of growing international interdependence, the powerseeking entrepreneurship by the Commission in light of the EU's fiscal disadvantage and support by export industries and state elites that believed regulation could best be handled at the EU level.

Research on European regulatory governance has focused on why EU institutions and bodies have been particularly successful at acquiring regulatory powers, which actors have had primary responsibility for establishing the EU as a regulatory state, explaining differences in regulatory powers across issues areas and how to ensure political accountability (Kohler-Koch and Rittberger, 2006: 35-36). One particular robust area of debate is over the extent to which regulation is actually Europeanized rather than nationalized (Eberlein and Grande, 2005: 92-93).

\section{Experimentalist governance}

A fourth strand of governance research is the study of experimentalist governance (Caporaso and Wittenbrinck, 2006; Eberlein and Kerwer, 2004; Sabel and Zeitlin, 2007; Zeitlin, 2011). According to one of its foremost proponents, experimentalist governance is defined as a "recursive process of provisional goal-setting and revision based on learning from the comparison of alternative approaches to advancing them in different contexts" (Zeitlin, 2011: 5). Experimentalism is said to form an "underlying architecture of public rule making in the EU", combining mutually agreed framework goals, subsidiarity in implementation, performance reporting and peer evaluation, and periodic revision of goals, metrics and procedures by a widening circle of relevant actors. The Open Method of Coordination (OMC) has received the bulk of experimentalist attention.

The EU's experimentalist architecture is said to be significant because it contrasts with government hierarchy and permits policy cooperation in areas where binding decisions are politically unpalatable. Experimentalism is said to be distinct from hierarchical government in four basic ways. First, there exists no clear distinction between policy conception and administrative execution. Goals and means are set through a repeated process of provisional goal-setting and execution. Second, experimentalism is neither centralized nor decentralized, but combines centrally coordinated learning with local experimentation. Third, experimentalism 
is neither formalized nor informalized, but "flexibly formalized", organized by well-defined rules and norms that are revised in light of experience. Fourth, compliance is not achieved through formal sanctions, but on the basis of good arguments regarding why one set of goals and means is preferable to another. In the absence of demonstrated success, compliance is achieved through self-correction and improvement.

The second way experimentalism is said to be important is that it allows for coordinated action in areas where the Union lacks legal competence and/or member states are hesitant to commit to binding targets or policies because of their political sensitivity. Because governments participate on a voluntary basis, it allows them to avoid the public scrutiny and conflict typical of reaching agreement over binding commitments (Caporaso and Wittenbrinck, 2006: 475). As one form of experimentalism, the OMC was initiated as part of the European Employment Strategy to allow for more informal, less hierarchical means of coordinating national policies in the areas of employment. The OMC was subsequently applied to other policy areas, including poverty and social exclusion, pensions, immigration, education and youth issues (Regent, 2003).

Explanations of the rise of experimentalist governance point to two scope conditions: strategic uncertainty and a polyarchic distribution of power. New developments like the globalization of production, transborder environmental effects and technological innovation lead to strategic uncertainty amongst political actors about policy goals and means, while dispersing influence to a variety of actors. Because actors do not know what precisely they want to achieve or how to do so, and because they depend on others for successful action, they are oriented towards deliberative problem-solving or experimentalism (Sabel and Zeitlin, 2007: 13-14; Zeitlin, 2011: 5-10). With respect to the development of the OMC, additional factors are also cited: the particular problems of factor and product market flexibility under EMU, the need to avoid public scrutiny and respect for national differences (Eberlein and Kerwer, 2004: 125; Hodson and Maher, 2001).

Research on experimentalism has explored variation in the effectiveness of the OMC across issue areas, its impact on national polices, the interests and motivations of significant actors, the extensiveness in its use, its openness to various actors and whether or not it will be a transitional mechanism preparing the way for the transfer of additional competences to the EU and away from individual states (Eberlein and Kerwer, 2004: 125-127; Hodson and Maher, 2001; KohlerKoch and Rittberger, 2006: 36-37).

Typically, then, scholars conceptualize European governance in contrast to government. In doing so, they break from statist paradigms emanating out of IR and comparativist research. Where government was about hierarchy and bureaucracy, governance refers to a new method, process or pattern of public rule - that is, a novel state formation. Although their concepts and theories overlap at times - and efforts have been made to combine various strands (see for instance Eberlein and 
Grande, 2005) - definitions of governance vary, as do the phenomena they name and explanations of how it arose. Furthermore, scholars make different claims about the significance of governance, research different questions and debate different issues. Table 1 summarizes the primary differences amongst the different strands of governance research.

\section{The Ideas that Govern Europe}

While overlapping in a limited way with existing research, the contributions to this Special Issue start from different premises about political action. These differences have significant implications for research on European governance. Most notably, it leads to rejecting efforts to build and test comprehensive theories of European governance and shifts attention to developing humanist and historicist explanations that expose complexity, diversity and contestation. In short, we advocate genealogical research on the ideas that govern Europe. ${ }^{6}$

We share the belief with other researchers that there exist patterns of governance in contemporary Europe, some of which are new. Regulatory provision is a central feature of the EU; networks of private and public actors contribute to the creation and implementation of policy; different levels of government interpenetrate and so on. Where our views differ decisively is over how we should explain these patterns (Bevir, 2013: 66-69). Theories of multi-level, network, regulatory and experimental governance explain the rise of European governance or its effects by reference to the existence of certain social facts. It is presumed that inhering in these facts is a social logic that produces patterns of behavior. Theories of European governance present themselves as comprehensive, mid-range theories by appealing to the existence of certain social facts that exhibit a social logic. To take one example, theories of MLG, regulatory governance and experimentalism cite the fact of interdependence as one factor that accounts for the new process, pattern or method of governance that they identify. A certain pattern of facts - interdependence - are said to explain another pattern of social facts - European governance.

In contrast, we believe that the aspiration to comprehensiveness and the positing of social logics is philosophically flawed. Social facts (like interdependence) or patterns of social facts cannot explain European governance. Social facts cannot explain political activity because humans are agents that act on beliefs and desires that are their own. Because humans are agents, social facts do not contain a social logic that explains some outcome. Rather, it is actors' ideas that do the explanatory work, including beliefs about interdependence. Indeed, if theories of European governance each capture some of the truth about the contemporary European political reality, what they reveal is that political actors have responded to the fact of interdependence in a variety of ways, producing a variety of governance practices. Other actors or the same actors in other contexts, of course, have carried 


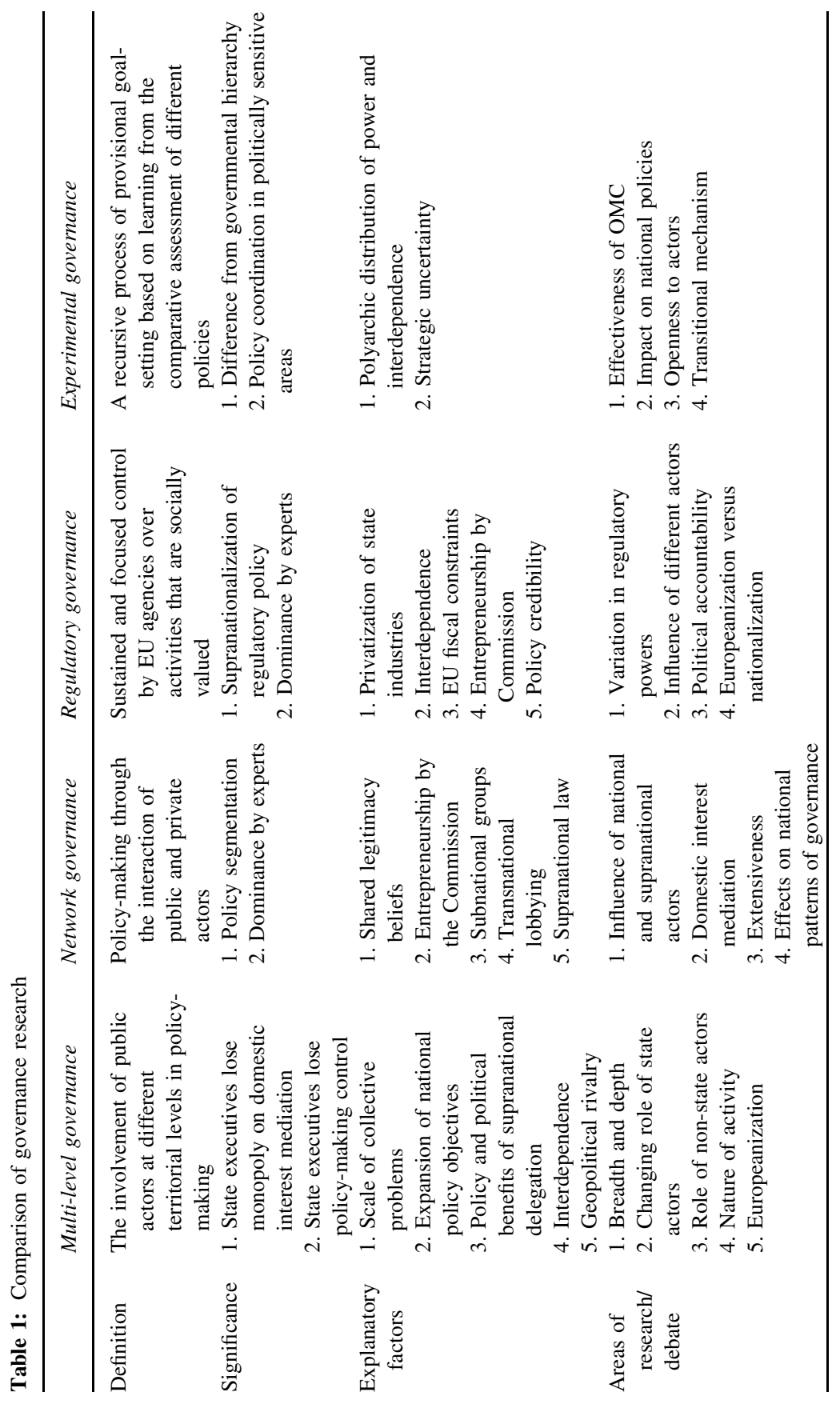


on as before either unaware that interdependence exists or believing it does not require the same sort of response across all settings. The fact of interdependence does not explain the new practices of European governance; actors' beliefs and preferences do. The development of a comprehensive theory of European governance is impossible because social facts do not contain social logics.

Because political actors are agents, our theories of European governance should be resolutely humanist in form. Candidate theories - that is, theories that in principle might have a claim on our allegiance - should be humanist in the sense that they will appeal to the actual beliefs and desires of those we study. Patterns of governance practices will be explained by reference to the beliefs and desires of those engaged in such practices. A theory of governance that appeals to interdependence as a social fact is not a candidate theory - meaning, it could not in principle be a true explanation - because it attempts to bypass the beliefs of actors or treats actors' beliefs as resulting from some deeper reality. ${ }^{7}$

Because candidate theories must explain practices of governance by reference to the beliefs and preferences of those engaged in those practices, this means that research should also be historical in nature. Political actors inherit some of their beliefs and the practices those beliefs inform from people who have come before them. Beliefs and practices are inherited through what can broadly be called "socialization". As a result, to explain the actions of those we study, we should develop historical narratives of how actors came to hold the beliefs and desires that they do.

In our view, then, existing research on European governance is better understood as descriptions of general patterns rather than comprehensive theories of governance. But as descriptions of general patterns, multi-level governance, network theory, regulatory governance and experimentalism need to be supplemented by ideational and historicist explanations. We need ideational and historicist explanations of the particular cases that give rise to the broader patterns of governance practices in contemporary Europe.

The focus on the ideas that govern Europe has one other important implication for research. It should be more attuned to complexity, diversity and contestation. Existing research on European governance suggests overly deterministic accounts of the rise of European governance and how it functions. Such an account makes sense if one thinks social facts like interdependence have some determinative social logic. But as just argued they do not. Alternatively, if one thinks - as we do - that political action is determined by people acting on some of their beliefs, then it suggests a much more contingent account of the historical emergence of patterns of governance. Given that political actors often hold different beliefs and preferences and struggle against one another in the determination of political action, historical research will frequently show how there existed a range of competing programs, drawing attention to the contingencies of practices. In the attempt to build comprehensive theories of European governance, too frequently scholars play 
down or ignore complexity, diversity and contestation. By contrast, humanist and historicist explanations should give these features greater prominence. For instance, in our study of the democratic reforms contained in the Lisbon Treaty, we demonstrate that actors responsible for negotiating treaty changes were influenced by a number of different "governance traditions" - or ideas about what made the EU legitimate. This resulted in different, conflicting proposals about how to improve the Union's democratic character. Because the Lisbon Treaty included reforms that were rooted in different governance traditions, EU democracy is a composite of concepts. Had actors mobilized around a different set of ideas or if certain ideas had been given greater prominence, then EU democracy would itself be different. Our study thus reveals the complexity, diversity and contestation that accompanied the democratic reform of the EU.

In sum, because governance, like all political action, is a practice informed by various ideas, we advocate a shift in attention to the concepts, beliefs and desires that actors use to govern Europe. Such a focus suggests the development of historical narratives to explain the emergence of such ideas and the governance practices that they support as well as greater attention to diversity, complexity and contestation.

\section{Summary of Contributions}

The articles in this Special Issue provide humanist and historicist explanations of contemporary practices of European governance. In doing so, they explore diversity, complexity and contestation. While many different ideas that are used to govern Europe call out for attention, the articles focus on scientific rationalities, elite narratives and meaningful practices. Each of the articles addresses one or more of these themes. In focusing on scientific rationalities, several articles demonstrate the impact of modernist social science on changing patterns of governance, such as the role of behavioral economics in promoting nudge technologies. Other contributions analyze the discourses and policies of political elites in their attempts to promote novel modes of governance. And some of the articles explore the myriad ways in which local actors have interpreted and thus forged governance practices on the ground. In summarizing each of the articles, we draw attention to the different themes that they address and how they exhibit the central characteristics of genealogy: diversity, complexity and contestation.

The articles by Katharyne Mitchell and Fernanda Nicola address the influence of scientific rationalities and elite narratives on social impact investing and the negotiations of the Transatlantic Trade and Investment Partnership (TTIP). Mitchell's article investigates the contingent origins of measuring social value in the rapidly expanding area of social impact investment. She demonstrates that assumptions regarding the scientific validity, neutrality and transparency of social 
metrics legitimize new forms of governance. In particular, social impact investing is used to nudge governments and the targets of investment (i.e. the needy) towards market-oriented solutions, one effect of which is to further sideline the state as a guarantor of social provision. Mitchell's research sheds light on the contingent origins of many of the ideas that underpin social impact investing, such as "best practices" and "evidence-based policy". These ideas originate with influential philanthropic actors like the Bill and Melinda Gates Foundation, and celebrity humanitarians like U2's Bono further disseminates such ideas by connecting policy-makers, financiers and philanthropists. Mitchell's article highlights the social scientific concepts and global network of elites that have given rise to the newest variant of philanthro-capitalism: social impact investing.

In her article, Fernanda Nicola investigates the difficulties of achieving EU-US regulatory cooperation in negotiating TTIP. She contends that existing theories of international regulatory cooperation and analyses of TTIP provide incomplete accounts of why EU and US negotiators have repeatedly clashed over regulatory cooperation. She demonstrates that agreement has been difficult in part because of the influence of different cost-benefit traditions on the negotiating positions of the two parties. Whereas the EU adopts the perspective of "institutional proportionality", the US approach is influenced by "law and economics". Nicola's article traces the contingent origins of these two traditions and demonstrates how diverse understandings of cost-benefit have influenced TTIP negotiations.

Emma Carmel's study of EU social policy and security policy highlights the contingent and politically contested origins of knowledge production and expertise. Carmel challenges a commonly held belief amongst EU scholars that expertise is best conceptualized as a neutral resource that gives those who possess it power over others in the policy-making process. Drawing on Foucault's notion of power/knowledge, Carmel demonstrates that expertise is itself the effect of power relations. In doing so, she draws attention to the ways various individuals and organizations participate in the production of expert knowledge about the EU and the governance policies and practices such knowledge informs.

William Walters' article addresses how the activities of EUROSUR, the EU's border surveillance system, are organized around the concept of "situational awareness". Walters research demonstrates that EU border control and policing embodies an emergent political rationality, whose peculiarities are missed if we approach EUROSUR as a problem-solving initiative or locate it as a case of the general phenomenon of securitization. Building on Foucauldian-inspired genealogies of security, including some of his own work, Walters argues that governance of the EU's southern border involves the production of a new temporality and spatiality. Within the framework of EUROSUR, there is a quest to produce realtime knowledge of border spaces - or "situational awareness" - to enable immediate, coordinated responses to migration and border policing - what Walters labels "live governance". Walters traces the diverse origins of situational 
awareness and demonstrates how it is implicated in material and technological practices of producing and securing the EU's southern border. In doing so, he denaturalizes what is emerging as taken for granted understandings about what the EU's border is and how it needs to be managed.

Finally, our article details more fully our understanding of the genealogical approach and investigates some of the elite narratives that contributed to democratic reforms contained in the Treaty of Lisbon. We argue that post-Maastricht (1993), the European Council, the European Parliament and the European Commission identified managing public opinion as a central purpose of treaty reform. The institutions publicly worried that a rising tide of Eurosepticism amongst the public threatened the functioning of the EU and endangered future plans. In this context, the institutions turned to improving the democratic character of the EU as a means to counter public opposition and increase public support for the EU. That is, the institutions turned to democracy as instrument of system maintenance. Agreement on the end (system maintenance), however, did not guarantee agreement on the means (democratic reform). The institutions made different and conflicting proposals regarding how to enhance the democratic character of the Union. We claim that key differences amongst the institutions' visions of a democratic Europe can be explained by relating them to three long-standing traditions in European governance: nationalism, federalism and technocracy. In the end, the Lisbon Treaty contained proposals and mixtures of proposals from each of the institutions. By exploring the diverse origins of the Lisbon reforms, our article underlines the contingent and contested nature of EU democracy.

\section{Conclusion}

This Special Issue demonstrates the usefulness of the historical investigation of ideas for the study of European governance. Whereas existing theories of European governance provide descriptions of general patterns, the articles of this Special Issue provide explanations of why some patterns exist. In particular, each of the articles sheds light on the influence of social scientific concepts, elite narratives and local traditions on the ways Europe is governed. In doing so, they draw attention to the contingency and diversity of ideas that are used to govern Europe.

In concluding this introduction, we want to suggest two implications of our historicist and humanist approach for a research agenda on European governance.

Several commentators have suggested that "scientific progress" in the study of EU governance requires a conceptual debate that will settle the definition of "governance" (Kohler-Koch and Rittberger, 2006: 43; Olsen, 2009: 192-193). If the point is that a settled definition will ease communication amongst researchers, we see nothing objectionable about trying to establish common usage. Alternatively, EU scholars might embrace Rhodes' (1996) suggestion to employ adjectival 
terms - e.g. multi-level governance, network governance, regulatory governance or experimental governance - to clarify distinct uses. However, given that the call for conceptual uniformity has emanated from researchers committed to the project of developing comprehensive, progressively scientific theories of European governance, we think that this desire carries a false promise. It is assumed that if researchers worked with a single definition of governance that referred to a single phenomenon, then more concentrated effort could be put towards specifying the common conditions or factors that produce European governance and its effects. Our understanding of the social logic of European governance, so the argument goes, is being obstructed by conceptual ambiguity and conflicting definitions.

Alternatively, we think that the term governance names a variety of contemporary practices in Europe. Moreover, as we have argued, European governance does not contain a social logic. As such, conceptual uniformity will not facilitate discovery of an underlying social logic of European governance. Instead, researchers should define their terms clearly in reference to those policies or practices they think they capture and develop genealogies of the ideas that have brought those policies or practices into existence.

Secondly, in our view, too much effort has been put into trying to identify the essence of EU and its predecessors: Is it an intergovernmental organization? Or a supranational functional polity? Is it sui generis or comparable to national political systems? Answers to these questions have then been the basis for choosing amongst modernist social scientific theories and methods. Of course, there are patterns of activities. But given that what the EU is the result of what EU actors do, ideal theorizations threaten to occlude the practical nature of the EU. Instead, research should be directed at the rationalities and narratives that inform actors' practices. Rationalities are the webs of belief that inform the actions of those we study. Our explanations of their actions should be oriented towards revealing a consistency between the beliefs they hold and the practices that they engage in. Our explanations of their beliefs should take a narrative form. Because governance practices - like all political action - are explained by reference to the beliefs that actors hold, we should be interested in how those we study came to hold those beliefs and not others. In terms of research, this suggests developing historical narratives about the origins of beliefs. The contributions to this Special Issue are examples of how this can be done.

\section{About the Authors}

Mark Bevir is a Professor of Political Science and the Director of the Center for British Studies at the University of California, Berkeley. He is also a Professor in the Graduate School of Governance at the United Nations University and a 
Distinguished Research Professor at Swansea University. He has published numerous books including Democratic Governance (Princeton, 2010) and A Theory of Governance (University of California, 2013).

Ryan Phillips is a C3 Mellon Postdoctoral Fellow in the Government \& International Relations Department at Connecticut College. His research interests are the European Union, democracy, genealogy and interpretivism. He is currently working on several articles that connect these themes as well as his book manuscript, The European Union and the Constitutionalization of Democracy.

\section{Notes}

1 That said, it would be misleading to claim that governance research enacted a clean break with the subfields of comparative politics or International Relations. It was scholars within CP and IR that produced original articulations of the idea of governance and identified some of the problems that public actors faced (Kohler-Koch and Rittberger, 2006, 2009: 4-11; Pollack, 2005: 380). It would be more accurate to say that researchers on European governance broke with statist traditions in CP and IR (Caporaso and Wittenbrinck, 2006: 471-473). We should add that our review of the literature is limited to publications in English.

2 Theorists of experimentalist governance treat it as both an empirical theory and normative ideal. Our interest is in the former.

3 This subsection draws on (Phillips, 2015).

4 In fact, John Peterson views MLG as one species of network theory (2004: 126-127).

5 This narrative is based on Majone (1994, 1999). Elsewhere, Majone refers to additional factors: American ideological influence, institutional isomorphism and shifting priorities of European governments (1996: 47-56).

6 For a view on the study of Europeanization that overlaps with our perspective on European governance, see Gerard Delanty and Chris Rumford's book Rethinking Europe: Social Theory and the Implications of Europeanization. We would like to thank one reviewer for this reference.

7 Even when existing research on European governance gives a nod to the importance of ideas (KohlerKoch, 1999; Majone, 1996: 49-54), it often remains confused about ultimate causes, often suggesting ideas are epiphenomena whose ultimate cause lay elsewhere.

\section{References}

Anderson, P. (2009) The New Old World. New York, NY: Verso Books.

Bache, I. and Flinders, M. (2004) Themes and issues in multi-level governance. In: I. Bache and M. Flinders (eds.) Multi-level Governance. Oxford: Oxford University Press, pp. 1-12.

Bevir, M. (2013) A Theory of Governance. http://escholarship.org/uc/item/2qs2w3rb, accessed 2 November 2015.

Bolleyer, N., Swenden, W. and McEwen, N. (2014) A theoretical perspective on multi-level systems in Europe: Constitutional power and partisan conflict. Comparative European Politics 12(4): 367-383.

Börzel, T.A. (1998) Organizing Babylon-On the different conceptions of policy networks. Public Administration 76(2): 253-273. 
Börzel, T.A. and Panke, D. (2013) Europeanization. In: M. Cini and N.P.-S. Borragán (eds.) European Union Politics, pp. 115-124.

Braun, M. (2009) The evolution of emissions trading in the European Union-The role of policy networks, knowledge and policy entrepreneurs. Accounting, Organizations and Society 34(3-4): 469-487.

Caporaso, J.A. and Wittenbrinck, J. (2006) The new modes of governance and political authority in Europe. Journal of European Public Policy 13(4): 471-480.

Delanty, G. and Rumford, C. (2005) Rethinking Europe: Social Theory and the Implications of Europeanization. New York: Routledge.

Dür, A. (2008) Bringing economic interests back into the study of EU trade policy-making. The British Journal of Politics and International Relations 10(1): 27-45.

Eberlein, B. and Grande, E. (2005) Beyond delegation: Transnational regulatory regimes and the EU regulatory state. Journal of European Public Policy 12(1): 89-112.

Eberlein, B. and Kerwer, D. (2004) New governance in the European Union: A theoretical perspective. JCMS: Journal of Common Market Studies 42(1): 121-142.

Eising, R. and Kohler-Koch, B. (1999) Introduction: Network governance in the European Union. In: R. Eising and B. Kohler-Koch (eds.) The Transformation of Governance in the European Union. New York: Routledge, pp. 3-13.

Fischer, M. and Sciarini, P. (2013) Europeanization and the inclusive strategies of executive actors. Journal of European Public Policy 20(10): 1482-1498.

Gillingham, J. (2003) European Integration, 1950-2003: Superstate or New Market Economy?. New York: Cambridge University Press.

Graziano, P. and Vink, M. P. (eds.) (2007) Europeanization: New Research Agendas. New York: Palgrave Macmillan.

Haas, E.B. (2004) The Uniting of Europe: Political, Social and Economic Forces, 1950-1957. Notre Dame, IN: University of Notre Dame Press.

Hix, S. (1994) The study of the european community: The challenge to comparative politics. West European Politics 17(1): 1-30.

Hix, S. (1998) The study of the European Union II: The 'new governance' agenda and its rival. Journal of European Public Policy 5(1): 38-65.

Hix, S. (2006) The European Union as Polity (I). In: K.E. Jørgensen, M. Pollack and B. Rosamond (eds.) Handbook of European Union Politics. Thousand Oaks, CA: Sage, pp. 142-158.

Hodson, D. and Maher, I. (2001) The open method as a new mode of governance: The case of soft economic policy co-ordination. JCMS: Journal of Common Market Studies 39(4): 719-746.

Hooghe, L. and Marks, G. (2008) European Union? West European Politics 31(1-2): 108-129.

Jachtenfuchs, M. (1995) Theoretical perspectives on European governance. European Law Journal 1(2): 115-133.

Jachtenfuchs, M. (2001) The governance approach to European integration. Journal of Common Market Studies 39(2): 245-264.

Jachtenfuchs, M. (2006) The European Union as a polity (II). In: K.E. Jørgensen, M. Pollack and B. Rosamond (eds.) The SAGE Handbook of European Union Politics. Thousand Oaks, CA: Sage, pp. 159-173.

Jordan, A. and Schout, A. (2006) The Coordination of the European Union: Exploring the Capacities of Networked Governance. Oxford; New York: Oxford University Press. http://public.eblib.com/choice/ publicfullrecord.aspx?p=737356, accessed 28 April 2016.

Kohler-Koch, B. (1999) The evolution and transformation of European governance. In: B. Kohler-Koch and R. Eising (eds.) The Transformation of Governance in the European Union. New York: Routledge, pp. 14-35.

Kohler-Koch, B. and Eising, R. (eds.) (1999) The Transformation of Governance in the European Union. London; New York: Routledge.

(c) 2016 Macmillan Publishers Ltd. 1472-4790 Comparative European Politics Vol. 15, 5, 685-704 
Kohler-Koch, B. and Rittberger, B. (2006) Review article: The 'Governance Turn' in EU studies. JCMS: Journal of Common Market Studies 44: 27-49.

Kohler-Koch, B. and Rittberger, B. (2009) A futile quest for coherence: The many frames of EU governance. In: B. Kohler-Koch and F. Larat (eds.) European Multi-level Governance. Northampton, MA: Edward Elgar, pp. 3-18.

Ladrech, R. (2010) Europeanization and National Politics. Basingstoke: Palgrave Macmillan.

Majone, G. (1994) The rise of the regulatory state in Europe. West European Politics 17(3): 77-101.

Majone, G. (1996) Regulating Europe. New York: Routledge. http://site.ebrary.com/lib/berkeley/reader. action?docID=10058173, accessed 22 October 2015 .

Majone, G. (1999) The regulatory state and its legitimacy problems. West European Politics 22(1): 1-24.

Marks, G., Hooghe, L. and Blank, K. (1996) European integration from the 1980s: State-centric v. multilevel governance. JCMS: Journal of Common Market Studies 34(3): 341-378.

Milward, A. (1984) The Reconstruction of Western Europe, 1945-51. Berkeley, CA: University of California Press.

Milward, A. (1999) The European Rescue of the Nation State. New York: Routledge.

Moravcsik, A. (1998) The Choice for Europe: Social Purpose and State Power from Messina to Maastricht. Ithaca, NY: Cornell University Press.

Olsen, J.P. (2009) EU governance: Where do we go from here? In B. Kohler-Koch and F. Larat (eds.) European Multi-level Governance: Contrasting Images in National Research. Northhampton, MA: Edward Elgar, pp. 192-209.

Perkmann, M. (1999) Building governance institutions across European borders. Regional Studies 33(7): 657-667.

Peterson, J. (2004) Policy networks. In: A. Wiener and T. Diez (eds.) European Integration Theory. New York: Oxford University Press, pp. 117-135.

Phillips, R. (2015) The European Union and the Constitutionalization of Democracy. Ph.D. dissertation, University of California, Berkeley.

Pollack, M. A. (2005) Theorizing the European Union: International organization, domestic polity, or experiment in new governance? Annual Review of Political Science 8(1): 357-398.

Regent, S. (2003) The open method of coordination: A new supranational form of governance? European Law Journal 9(2): 190-214.

Rhodes, R.A.W. (1996) The new governance: Governing without government. Political Studies 44(4): 652-667.

Sabel, C.F. and Zeitlin, J. (2007) Learning from difference: The new architecture of experimentalist governance in the European Union. European Governance Papers (EUROGOV) No. C-07-02: 1-69.

Schout, A., Jordan, A. and Twena, M. (2010) From 'old' to 'new' governance in the EU: Explaining a diagnostic deficit. West European Politics 33(1): 154-170.

Zeitlin, J. (2011) Transnational Transformations of Governance: The European Union and Beyond. Amsterdam, NLD: Amsterdam University Press. http://site.ebrary.com/lib/alltitles/docDetail. action?docID=10459445, accessed 20 August 2015. 